\title{
Silent Indignation--George Orwell's Wintry Conscience from Marrakech
}

\author{
Li Ling \\ Nanchang Institute of Science and Technology, Nanchang, 330108
}

Keywords: George Orwell, Marrakech, colonialism, conscience, metaphor, analogy

\begin{abstract}
Marrakech tells what the author, George Orwell, see, hear, and feels in the inside city of Morocco, which is colonized by France and Spain at that time. In Marrakech, George Orwell vividly and objectively described six isolated scenes: an ordinary and simple funeral; a man hired by government begging for bread; awkward situation of Jewish; the poor farming condition for peasants; an old woman carrying heavy burden; the black soldiers marching. Orwell shows the readers a profoundly suffering nation and his hostile attitude towards the injustice of the society. Suppressing his indignation, George makes no comment on what he sees and hears, however, he indicates the truth that the colonized imperialism is built on all these very facts. George Orwell expresses his deep sympathy for the poor colonized people and especially women through metaphor and analogy in his honest words, reflecting the crimes of colonialism and imperialism. For all of these, George Orwell defines the wintry conscience of a generation.
\end{abstract}

\section{Introduction}

Eric Arthur Blair (25 June 1903- 21 January 1950), better known by his pen name George Orwell, was a famous British novelist, journalist, essayist, and critic. He was born in India which was a colony of Britain at that time, then he came back to Britain with his family. At 7 , he was sent to a private boarding school. During this schooling time, George experienced class difference in Britain which influenced his concept of class greatly. When he was 15, George was enrolled in the best known school in Britain-- Eton. After graduating from Eton George Orwell served for the police station in Burmese (a British colony) for 5 years. Then he went back to London and started to wander from London to Paris ${ }^{[1]}$. Before World War II, George Orwell has engaged in Spanish Civil War and got wounded in that war. Because of the experience in World War II, George hated Totalitarianism and was in favor of Democratic Socialism ${ }^{[2]}$. Marrakech is one of his works, he composed it when he recuperated in Morocco. Orwell wrote literary criticism, poetry and polemical journalism. He is best known for the allegorical novella Animal Farm(1945) and the dystopian novel Nineteen Eighty-Four (1949). His works is marked by lucid prose, awareness of social justice. George Orwell hated both Totalitarianism and Colonialism and he sympathized the poor deeply. The British famous writer and critic V.S Pritchett called him "The Wintry Conscience of a Generation" [3].

\section{Scene 1}

At the beginning of Marrakech, George Orwell shows us a disgusting picture by describing "As the corpse went past the flies left the restaurant table in a cloud and rushed after it, but came back a few minutes later". The dead body was wrapped in a piece of rag and was placed on a rough wooden bier. A group of mourners--all men and boys without woman came across the mass market then arrived a burying ground. Actually it was not a burying ground, it was a huge waste of earth. The mourners "hack" an oblong hole (a foot or two deep), "dump" the body in it and "fling" over it with a little of the dried-up earth. No gravestone, no name, no identifying mark of any kind. A month or two later no one can even know where his own relatives are buried. The dead person cannot get the respect they deserve and they were thrown away like rubbish.

The dead returns to the earth, while how about the people who are alive? They come to this world, toiling, starving, returning to the dust years later, ragged and destitute, and passing away 
unnoticed. We cannot help asking, if life is light because of poverty, then what makes life so undignified? The author does not seem to have answered, but a brief description of the chaotic bazaar through which the funeral procession passed at the beginning seems to reveal: "piles of pomegranate and the taxis and the camels". There was a taxi in this poor place where all transport were by manpower or camels! This seemingly inadvertent description implies the author's indignation and deep thought about the gap between the rich and the poor. It also makes readers wonder who is the White man in car. A colonial official from France? Or his family member?

\section{Scene 2}

An Arab navvy worker asked for bread when seeing the writer (a white man) feed a gazelle with bread in the park. The digger put heavy hoe down, "sidled" slowly. Looking from the gazelle to the bread and from the bread to the gazelle, with a sort of quiet amazement, finally the worker summoned up courage to ask for bread in French. After receiving a piece of bread, he gratefully "stowed" the bread and placed it "in some secret place under his rags" ${ }^{[4]}$. The author seemed insouciant to tell us that the Arab worker who asked for bread is an employee of the municipality, and the story abruptly came to end.

The story seems to end abruptly and hastily, but it actually provokes a lot of thoughts and feelings from the readers. Due to the long-term colonization and slavery of western imperialism, the colonial people had a kind of unexplainable awe towards the white people and felt "shy" in front of the white people. The life of a municipal employee is so difficult that the situation of ordinary people is even more conceivable. Colonization is the culprit!

\section{Scene 3}

The third incident Orwell described is the life of the Jewish Quarters. The author first presents the living environment of the Jewish: "overcrowding", many of the streets are a good deal less than six feet wide, the houses are completely windowless, and sore-eyed children "cluster" everywhere in unbelievable numbers, like clouds of flies. Down the centre of the street there is generally running a little river of urine. For such a crowded, dirty and chaotic environment of non-human habitation, the author does not berate and scold bitterly, but calmly says that those children who are crowded everywhere and densely packed are like "cloud of flies". There is no happy, innocent, youthful childhood in the Jewish quarters, where children are grimy and vulgar, just like flies.

It looks like a paradise for flies, and even dark Jewish booths that look like caves are fly-infested. When the writer is passing a booth with a fired cigarette, instantly, from the dark holes all round, there was a frenzied rush of Jews". Old grandfathers with flowing grey beards, even a blind man somewhere at the back of one of the booths crawled out, they want cigarette. None of these people works less than twelve hours a day, and every one of them looked on a cigarette as a more or less impossible luxury.

For such difficult circumstances of Jews, there are various rumors among Arabs and Europeans poor. These "cunning" Jews robbed their jobs. They pretended to be poor in fact they are money lenders. Why so vicious! Orwell must have been angry about it too, but he knew clearly that his mission was to show the truth and not to comment it with personal feelings. So he moved on tell a seemingly disparate story by analogy: " a couple of hundred years ago, poor old women used to be burned for witchcraft when they could not even work enough magic to get themselves a square meal" [4]. The Jews lived in vicious ignorant gossip and prejudice.

\section{Scene 4}

Morocco's land is so desolate that " no wild animal bigger than a hare can live on it". "Huge areas which were once covered with forest have turned into a treeless waste where the soil is exactly like broken-up brick". What turned nutritious earth into a treeless waste and broken-up brick? 
Farming on the land exactly like broken-up brick, the intensity of labor is" frightful". Everything was done by hand, and the women pulled up the thorny weeds with their hands, and even the lucerne, which was harvested for forage, was not harvested, but uprooted with their hands, so that they could pick up an inch or two more of the stubble of lucerne.

The plough, made of wood, was "wretched, frail," and fitted underneath with a rough iron spike, which could only plough into the soil about four inches deep. Two animals when they were tied together could plough that deep. The odd thing is Moroccans farm with a cow and a donkey because two donkeys are too weak while two cows could cost a little more to feed.

Such poor countries in Asia and Africa are seen as tourist attractions. When people working in the fields dry land, cactus, distant mountains can be seen, but no farmers working in the fields, because their skin color and soil color are the same. In the eyes of European settlers, Morocco was an orange grove or a vacancy of government officials, or camels; castles; palm trees; foreign troops, brass trays or bandits, while the colonists gave brazen reasons for the extreme hardship of Moroccans. We Can Not see It! Is it prejudice, ignorance, or loss of conscience?! Orwell exposed the sinister motives of European settlers who ignored Moroccan poverty and were comfortable with it.

\section{Scene 5}

When we say women in Morocco suffer from sex discrimination, the suffering of old woman is far more than that. Every afternoon, a group of very old women carrying a load of firewood passed by Orwell's house. Each of these old women was "mummified with age and the sun, and all of them are tiny". They shrink to the size of children. Only in "very occasional cases" will you notice the little old woman covered by a load of firewood. As a result, old women who get used to being ignored and treated like animals shouldering a vast load of wood will panic and scream when you accidentally "notice" them. Orwell refrained from anger and spoke of his anger by describing a truth that people in Morocco could be angry for seeing the donkey carry too much weight. The plight of the donkey makes people "angry", but people do not feel angry when seeing old woman carrying too much weight. In you will notice the donkey with the heavy load in less than five minutes after landing on Moroccan, however in "a few weeks" you will not notice the old woman with the firewood. Seeing the suffering of the poor in Morocco Orwell can do nothing. Even worse he has to conceal his anger. How did Orwell suffer in his heart!

\section{Scene 6}

When telling the story of the black soldiers on the march, Orwell began and ended the story with stork, which flew toward north and the black march to south. Such a scene of confrontation and conflict goes through the whole story, symbolizing the sharp conflicts between the white colonists and the black people in colonies. Although the black people are not aware of this, "How much longer can we go on kidding these people? How long before they turn their guns in the other direction?" [4] the soldiers' burly bodies were hidden in their yellow-caked uniforms, their feet squashed into wooden boots and their helmets seemed to be a couple of sizes too small. These ill-equipped black soldiers, who marched long distances in the sweltering heat, did not complain, and their eyes were free from hostility, contempt, sulk, or even curiosity. They showed respect for the white person, as if they were "shy" at the presence of their host because they were always told that the white person is the master, and they were "convinced." Orwell's feelings for black people were complicated: he sympathized their misfortunes, he was angry too. White people are already scared, but black people didn't know that. Although the armed men, like the meek oxen, marched peacefully, the evil colonialism was doomed to end. White stork flying overhead like scraps of paper silver colored, and it is prediction and expectation to the end of colonialism by Orwell. 


\section{Conclusion}

It is too easy to attribute Moroccan endless suffering to colonialism. Colonialism doesn't bring about lower social status of Muslim women. The bad living environment of Jewish also is not a direct result of colonialism. Racial and sex discrimination in Marrakech are not the result of the colonial rule. But there is no doubt that colonialism (imperialism) has greatly deepened the poverty and backwardness of Morocco, and it is sinful, unforgivable and doomed to collapse for building a colonial empire on an already miserable reality. In those dark days, Orwell spoke with a Wintry Conscience for the freedom of the poor, expecting their awakening and then bury the colonial empire.

\section{References}

[1] Liu Bingshan. The Brief History of British Literature (Additional) [M]. He'nan People's Press. January, 2007

[2] Orwell. Why I Write [M]. Translated by Dong Leshan. Shanghai Translation Press.2007

[3] Jeffrey Meyers. Biography of Orwell [M]. Translated by Sun Zhongxu. Orient Press.

[4] Zhang Hanxi. Advanced English (Revised) 2 [M]. Beijing: Foreign Language Teaching and Research Press. October, 2010

[5] Chen Zhenglun, Tang Ping. A Cross-cultural Study of Marrakech by Gorge Orwell [J]. Journal of Yibin Institute. 2007 (3) 